\title{
The effect of chain extender structure on the enzymatic degradation of carbohydrate based polyurethane elastomers
}

\author{
Joanna Wojturska ${ }^{1)}$ \\ DOI: dx.doi.org/10.14314/polimery.2020.2.6
}

\begin{abstract}
Polyurethane elastomers (PUR) based on 2,2,4(2,4,4)-trimethyl-hexamethylenediisocyanate (TMDI) and polyestrodiol (Desmophen D1200) were prepared using various carbohydrates or their derivatives: monosaccharide (glucose), disaccharide (sucrose), sugar alcohol (mannitol and sorbitol). The effect of stoichiometry of ingredients and type of carbohydrates is discussed in relation to their susceptibility to enzymatic degradation catalysed by lipase from Candida antarctica (Novozym 735). The study supports the suitability of carbohydrates or sugar alcohols as important components of PUR for biomedical applications.
\end{abstract}

Keywords: polyurethane, carbohydrates, enzymatic degradation, surface structure, morphology, roughness, topography.

\section{Wpływ budowy chemicznej przedłużacza łańcucha na degradację enzymatyczną elastomerów poliuretanowych otrzymanych z wykorzystaniem węglowodanów}

Streszczenie: Elastomery poliuretanowe (PUR) otrzymano z wykorzystaniem 2,2,4(2,4,4)-trimetyloheksametylenodiizocyjanianu (TMDI), poliestrodiolu (Desmophen D1200) oraz różnych węglowodanów lub ich pochodnych: monosacharydu (glukozy), disacharydu (sacharozy), alkoholi cukrowych (mannitol i sorbitol). Określono wpływ stechiometrii składników i rodzaju węglowodanów na podatność otrzymanych poliuretanów na degradację enzymatyczną katalizowaną lipazą uzyskaną z Candida antarctica (Novozym 735). Potwierdzono możliwość wykorzystania węglowodanów i alkoholi cukrowych jako istotnych składników PUR do zastosowań biomedycznych.

Słowa kluczowe: poliuretan, węglowodany, degradacja enzymatyczna, struktura powierzchni, morfologia, chropowatość, topografia.

Degradation of polyurethanes (PUR) has attracted great interest of researchers especially because polyurethanes are expanding to newer horizons in the field of biomedical sciences, particularly due to their exceptional set of properties that deem fit for applications in the said field [1]. The synthesis of polymers from carbohydrate-derived building blocks may lead to novel materials which could be employ such polymers in biomedical applications such as drug delivery devices, implants, scaffolds for tissue engineering, etc. Carbohydrates find increasing attention as components of biomedical devices due to their easy availability from renewable resources [2]. PUR shows degradation capability in the presence of some hydrolytic enzymes. Enzymatic degradation was carried out with the use of hydrolases [3], lipases (from

\footnotetext{
1) Rzeszów University of Technology, al. Powstańców Warszawy 6, 35-959 Rzeszów, Poland.

e-mail: nogaj@prz.edu.pl
}

R. delemar [4, 5], Candida rugose [6]), proteases (papaine, bromelain, $\alpha$-chymotrypsin) [7], cholesterol esterase [8], amidases $[9,10]$. Reports indicate that enzymes mainly degrade elastic segments. Additionally, decomposition of hard segments occurs and the level of their degradation is a function of the segment size and structure. Hydrolysis of the elastic segments is significantly faster than the hydrolysis of urethane bonds which constitute a part of the hard domain [11].

While assessing the impact of the microstructure of urethanes on the degradation capability of PUR it was found that the chemical structure of specific segments, the degree of phase separation and the degree of crystallinity all have significant impact on the rate of degradation. Adequate choice of the chemical structure of the soft segment is decisive for the fact whether the degradation will take years or if it will occur within several weeks [12].

Another decisive factor for enzymatic degradation is the structure of hard segments, their contents in a macro- 
molecule and the range of effects within the same segment, because they lead to a reduction in the mobility of a polymer chain [13]. Capability of PUR to establish microdomains consisting of hard segments, may result in the fact that potential locations susceptible to hydrolytic assault (urethane, urea and carbonate bonds) are concealed or camouflaged, as a consequence hindering the process of degradation. It has been demonstrated that there is a strong correlation between the structure of the hard segment and the speed of degradation - the larger the number of urea or urethane bonds the slower the degradation process. The capability of the hard segment in polyurethanes to fulfil a protective function against hydrolysis may partly result from the presence of hydrogen bonds inside the hard segments. Additionally, the presence of hard microdomains in polyurethane depends on the conditions of processing, i.e. temperature and mechanical tensions which may facilitate the occurrence of these segments [14].

The structure of PUR was modified by means of mono-, di-, oligo- and polysaccharides constituting the polyol component as well as an extension or crosslinking agent (1,4:3,6-dianhydrohexitols) [15, 16], glucose [17, 18], sugar alditols [19], chitin [20], chitosan [21-23], maltodextrin [24], sucrose, starch and cellulose [25] There are numerous examples of PUR synthesis of this type, and attention is paid to their mechanical and thermal resistance. There have also been studies aimed at assessing their hydrophilicity, yet there are very few reports regarding attempts to carry out enzymatic degradation of polymers modified in this way, or attempts involving their biodegradation in other environments (in soil or against isolated bacteria) [26]. The manipulation of PUR by carbohydrate has solved the major concern of biodegradability, biocompatibility and economy. This knowledge could facilitate the selection of more efficient approach for synthesis of polymeric systems based on the biological macromolecules [2].

\section{EXPERIMENTAL PART}

\section{Materials and processes}

\section{Synthesis of polyurethanes}

The polyurethanes were synthesized by the conventional two-step polymerization method, which involved either hydroxyl-terminated, aliphatic polyestrodiol Desmophen 1200 (D1200, slightly branched, hydroxyl-bearing polyester, $\mathrm{LOH}=165 \mathrm{mg} \mathrm{KOH} / \mathrm{g}$ ), kindly donated by Bayer, a selected diisocyanate: mixture of 2,2,4(2,4,4)-trimethyl-hexamethylenediisocyanate (TMDI), kindly donated by Evonik Degussa.

In the first stage, diisocyanate and polyestrodiol at a molar ratio of $2: 1$ were reacted to form the prepolymer. The reaction was performed in the $\mathrm{N}, \mathrm{N}$ -dimethylacetamide (DMAC) (75\% solution). No catalyst was applied. The mixture was stirred at $80^{\circ} \mathrm{C}$ under dry nitrogen until the amount of NCO reached the theoreti- cal value determined by the dibuthylamine back-titration method. Isocyanate prepolymer obtained in this way was then converted into the final product by further reaction with the chain extender [various plant components: glucose - GLU, sucrose - SUC or sugar alcohols (mannitol MAN, sorbitol - SOR)].

The second stage of the synthesis was performed in two alternative ways differing in the amount of the applied chain extender. Thus, in variant I stoichiometric amount of the chain extender was used so that each $\mathrm{OH}$ group of the extender was matched by one NCO group of the prepolymer (the subtle reactivity differences between primary and secondary hydroxyl groups have not been considered).

Variant II applied one mol of chain extender per each NCO group of the prepolymer which means there was a significant excess of this reagent (in the case of GLU 5-times, SUC 8- times, MAN and SOR 6- times).

The liquid compositions were poured into prepared polytetrafluoroethylene molds. The second stage of the polymerization process was realized at $80^{\circ} \mathrm{C}$, over 72 hours.

This allowed for obtaining 8 polyurethane samples differentiated by the type and amount of the applied chain extender. In order to facilitate their identification the samples were assigned adequate symbols reflecting their chemical composition. Because each of the synthesized polyurethanes contained TMDI and D1200, these components were not taken into account in the sample marking code. Polyurethanes were marked in accordance with the following pattern: PUR-type of the chain extender variant of the synthesis. For instance, the sample marked with PUR-SUC-1 refers to the polyurethane obtained from TMDI, D1200 and sucrose used as the chain extender, with sucrose applied in stoichiometric ratio calculated per the number of free NCO groups of the prepolymer.

The compositions that were utilized were presented in Table 1.

\section{Degradation of polyurethanes}

Obtained films were cut into pieces $15 \times 20 \mathrm{~mm}$, weighted and then samples were treated at $37^{\circ} \mathrm{C}$ for 42 days by lipase from Candida antarctica (Novozym 735) to generate enzymatic degradation (6000 enzyme units per gram of the sample). The enzyme was kindly donated by Novozymes. In order to control the microbial contamination of samples, $0.2 \mathrm{wt} \%$ sodium azide was added into the solutions. After the treatment, samples were removed, cleaned by sonication in 1\% Triton X100 and rinsed thoroughly three times in deionised water. Samples were than dried at $40{ }^{\circ} \mathrm{C}$ until achieving the constant mass.

\section{Methods of testing}

\section{Surface characterization by optical microscopy}

The microstructural characteristics of the polyurethane samples before and after enzyme treatment were 
T a b l e 1. Nomenclature for the polymers

\begin{tabular}{c|c|c|c|c}
\hline Sample & $\begin{array}{c}\text { D1200 } \\
\text { mol }\end{array}$ & $\begin{array}{c}\text { TMDI } \\
\text { mol }\end{array}$ & $\begin{array}{c}\text { Chain extender } \\
\text { mol }\end{array}$ & $\begin{array}{c}\text { NCO content } \\
\text { after I stage } \\
\text { mol }\end{array}$ \\
\hline PUR-GLU-1 & & & $4.0 \cdot 10^{-3}$ & \\
PUR-SUC-1 & 0.01 & 0.02 & $2.5 \cdot 10^{-3}$ & \\
PUR-MAN-1 & & & $3.3 \cdot 10^{-3}$ & 0.02 \\
PUR-SOR-1 & \multirow{2}{*}{0.01} & & $3.3 \cdot 10^{-3}$ & \\
PUR-GLU-2 & & 0.02 & 0.2 & \\
PUR-SUC-2 & & & 0.2 & \\
PUR-MAN-2 & & & 0.2 & \\
PUR-SOR-2 & & & 0.2 & \\
\hline
\end{tabular}

examined by using an optical polarizing microscope Nikon Eclipse LV100 POL.

\section{Roughness analysis by confocal microscopy (CM)}

Roughness determination analysis of the samples before and after enzyme treatment was examined by using a confocal microscope. Images were obtained using "usurf explorer" NanoFocus AG microscope which combines a $505 \mathrm{~nm}$ laser with optics specifically designed for operation at this wavelength (optical modules: magnification 10×, measuring field $\left.1600 \times 1600 \mu \mathrm{m}^{2}\right)$. The instrument can measure a roughness profile or provide roughness parameters such as roughness average $\left(R_{a}\right)$, root mean square (RMS) roughness $\left(R_{q}\right)$, maximum height of the profile $\left(R_{t}\right)$, average maximum height of the profile $\left(R_{z}\right)$, maximum roughness depth $\left(R_{\max }\right)$.

\section{Evaluation of the mass loss of polyurethane samples}

The extent of degradation was determined by calculating the percentage of mass loss:

$$
\Delta W=100 \cdot\left(W_{0}-W_{\mathrm{t}}\right) / W_{0}
$$

where: $W_{0}$ - the dry mass before degradation, $W_{\mathrm{t}}-$ the dry mass after enzymatic degradation.

\section{FT-IR ATR}

Fourier transform infrared (FT-IR) spectra were obtained at room temperature using Nicolet 6700 (Thermo Scientific) spectrophotometer. The spectra of synthesized and degraded polyurethane samples were recorded in the range of $400-4000 \mathrm{~cm}^{-1}$ with nominal resolution of $4 \mathrm{~cm}^{-1}$ by ATR (attenuated total reflection) technique.

\section{Determination of surface energy}

Total free surface energy $\left(\gamma_{\mathrm{s}}\right)$, was quantified using a contact angle goniometer made by Cobrabid-Optic (Poland). The pair of immersed liquid (diiodomethane- -water) was chosen. Measurements were realized at $22 \pm 1{ }^{\circ} \mathrm{C}$.

The Owens-Wendt theory divides the surface energy into two components: surface energy due to dispersive interactions $\left(\gamma_{\mathrm{s}}^{\mathrm{d}}\right)$ and surface energy due to polar interactions $\left(\gamma_{\mathrm{s}}^{\mathrm{p}}\right)$.The total surface free energy of the solid is then given by the equation:

$$
\gamma_{S}=\gamma_{S}^{d}+\gamma_{S}^{p}
$$

Contact angles of the chosen pairs of liquid, with known values of $\gamma_{s}^{\mathrm{d}}, \gamma_{\mathrm{s}}^{\mathrm{p}}$, are put into the following equation [27]:

$$
\gamma_{L} \frac{1+\cos \theta}{2}=\left(\gamma^{d}+\gamma_{L}^{d}\right)^{0.5}+\left(\gamma^{p}+\gamma_{L}^{p}\right)^{0.5}
$$

where: $\gamma$ refers to surface free energy, the subscripts $\mathrm{L}$ and $S$ refer to liquid and solid, and the superscripts $p$ and $\mathrm{d}$ refers to polar and dispersive components.

The Owens-Wendt theory is typically applicable to surfaces with low charge and moderate polarity. Some good examples are polymers that contain heteroatoms, especially polyurethanes.

Surface free energy quantifies the characteristics of the solid and mediates the properties of the solid substrate and can be regarded as the "surface tension" of the solid substrate, which is a characteristic property of the solid in the same way as the surface tension is for a liquid.

\section{Thermal analysis}

Differential scanning calorimetry scans were recorded using $10 \mathrm{mg}$ sample under nitrogen flow with a Mettler Toledo 822e thermal analysis instrument, in the temperature range $-40-100{ }^{\circ} \mathrm{C}$ at a heating rate $10 \mathrm{deg} / \mathrm{min}$. The glass transitions temperatures $\left(T_{g}\right)$ were calculated as the midpoint of the heat capacity change.

TG/DTA measurements of the samples were carried out with Mettler Toledo TGA/DSC1. The heating rate was $20^{\circ} \mathrm{C} / \mathrm{min}$ in the range from 25 to $800{ }^{\circ} \mathrm{C}$. The flow rate of carrier gas was $50 \mathrm{~cm}^{3} / \mathrm{min}$ and sample weight was about $2 \mathrm{mg}$. 
Thermal analysis was realized for samples before and after degradation test.

\section{Efficiency of enzymatic degradation}

Enzymatic degradation of polyurethane films was specified by the rate of their solubilization which was determined by measuring the water-soluble total organic carbon (TOC) concentrations. Those values were measured by total organic carbon analyzer (Shimadzu Scientific Instruments, Inc., TOC- $\mathrm{V}_{\mathrm{CPN}}$ ).

Net TOC $\left(T O C_{N}\right)$ values were calculated according to the equation, as follows [28]:

$$
\mathrm{TOC}_{\mathrm{N}}=\mathrm{TOC}_{\mathrm{S}, \mathrm{E}, \mathrm{B}}-\mathrm{TOC}_{\mathrm{E}, \mathrm{B}}-\mathrm{TOC}_{\mathrm{S}, \mathrm{B}}
$$

$\mathrm{TOC}_{\mathrm{S}, \mathrm{E}, \mathrm{B}}$ - total organic carbon concentration in the solution which contains sample, enzyme and buffer, ppm

$\mathrm{TOC}_{\mathrm{E}, \mathrm{B}}$ - total organic carbon concentration in the solution which contains enzyme and buffer, ppm

$\mathrm{TOC}_{\mathrm{S}, \mathrm{B}}$ - total organic carbon concentration in the solution which contains sample and buffer, ppm

Efficiency of degradation $\left(E_{\text {bio }}\right)$ was expressed via the equation:

$$
E_{\text {bio }}=\frac{\text { TOC }_{\mathrm{N}}}{\text { TOC }_{\mathrm{T}}} \cdot 100 \%
$$

$\mathrm{TOC}_{\mathrm{N}}$ - theoretical value of total organic carbon, ppm;

$\mathrm{TOC}_{\mathrm{T}}$ - theoretical total value of organic carbon denotes TOC in the polymer sample, ppm.

\section{The swelling behavior}

The sorption studies were carried out by the reported procedure [29]. The sorption was carried out at $25{ }^{\circ} \mathrm{C}$ in chlorobenzene as nonsolvent. The data obtained from the sorption experiments were used to calculate the average molecular weight between crosslinks $\left(M_{c}\right)$ from the Flory-Rhener equation

$$
M_{c}=\frac{\varrho_{\mathrm{p}} \cdot V_{\mathrm{S}} \cdot \Phi^{1 / 3}}{\ln (1-\Phi)+\Phi+\Phi^{2}}
$$

where $\varrho_{p}$ - the density of polymer, $\mathrm{g} / \mathrm{cm}^{3}, V_{\mathrm{s}}$ - the molar volume of solvent, $\mathrm{cm}^{3} / \mathrm{mol} ; \Phi$ - the volume fraction of polymer in the swollen gel, $\chi$ - the polymer-solvent interaction parameter.

The degree of crosslinking $(v)$ was inversely proportional to the molecular weight between crosslinks.

$$
v=\frac{1}{2 M_{c}}
$$

\section{RESULTS AND DISCUSSION}

Many factors such as hydrophobicity of the surface, molecular mass of the polymer or the chemical structure of the polymer chains have been thought to be respon- sible for controlling the degradability of polyurethanes. After implantation, biodegradable polymers may undergo a variety of changes in their physicochemical properties as a result of degradation. The main changes are related to the ones occurring on the polymer surface, such as increase of surface roughness and free surface energy. In the case of this work it was found that the most important factor determining the rate of enzymatic degradation were the type and amount of the extender incorporated into polymer synthesis.

Enzymatic degradation caused macroscopic changes in the appearance of all the samples. After enzymatic degradation, the samples lost their transparency and gloss and became yellow (initially, they were colourless). The influence of the polyurethane chemical structure on the microscopic changes of the appearance of the samples after degradation was evaluated. Physical changes (formation of surface defects) caused by enzymatic hydrolysis were visualized by means of optical microscopy. The amount of the extender used, turned out to be the most significant factor for the course of enzymatic degradation. Superficial changes were decidedly more visible for samples, in which an excessive amount of the extend-
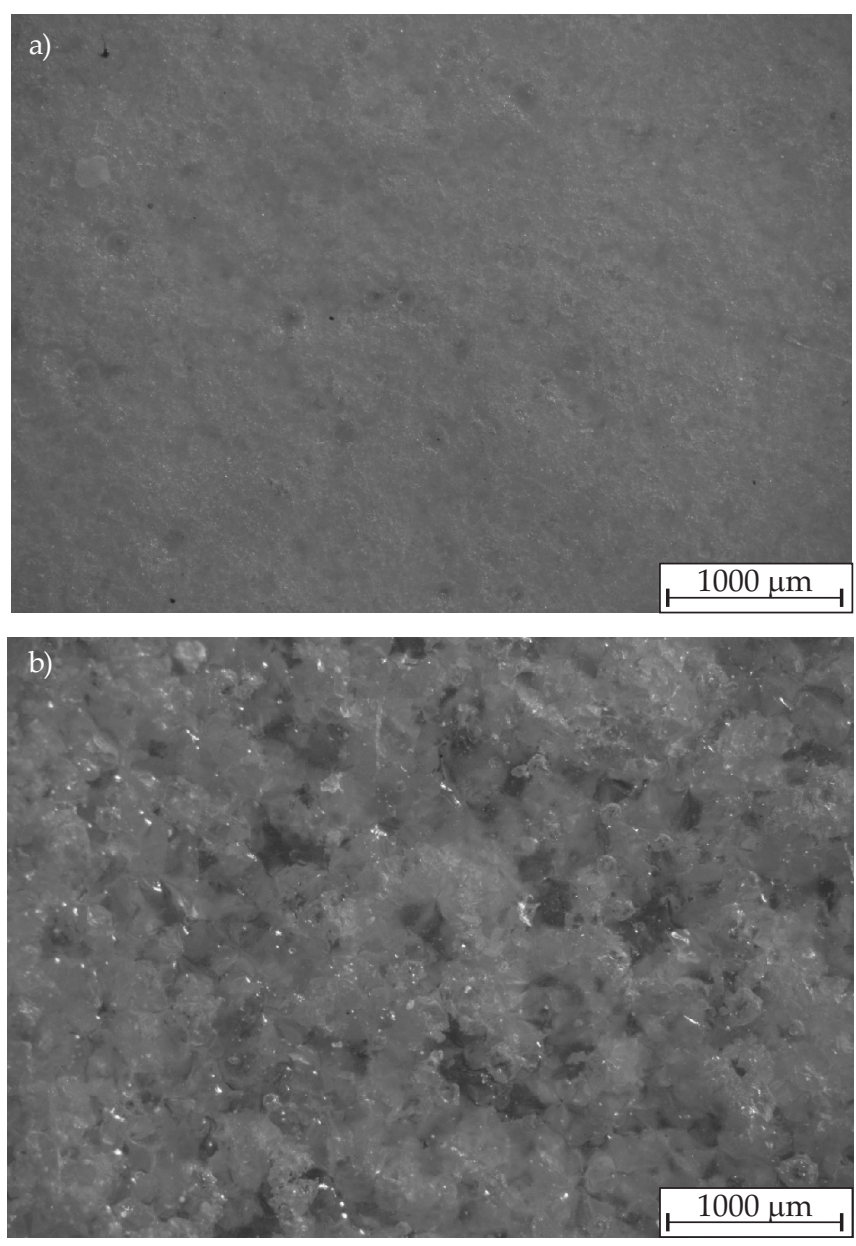

Fig. 1. Typical optical microscopy images graph of surface of PUR samples obtained from TMDI, D1200 and sucrose (variant II): a) original film, b) polyurethane films after degradation in Novozym 735 


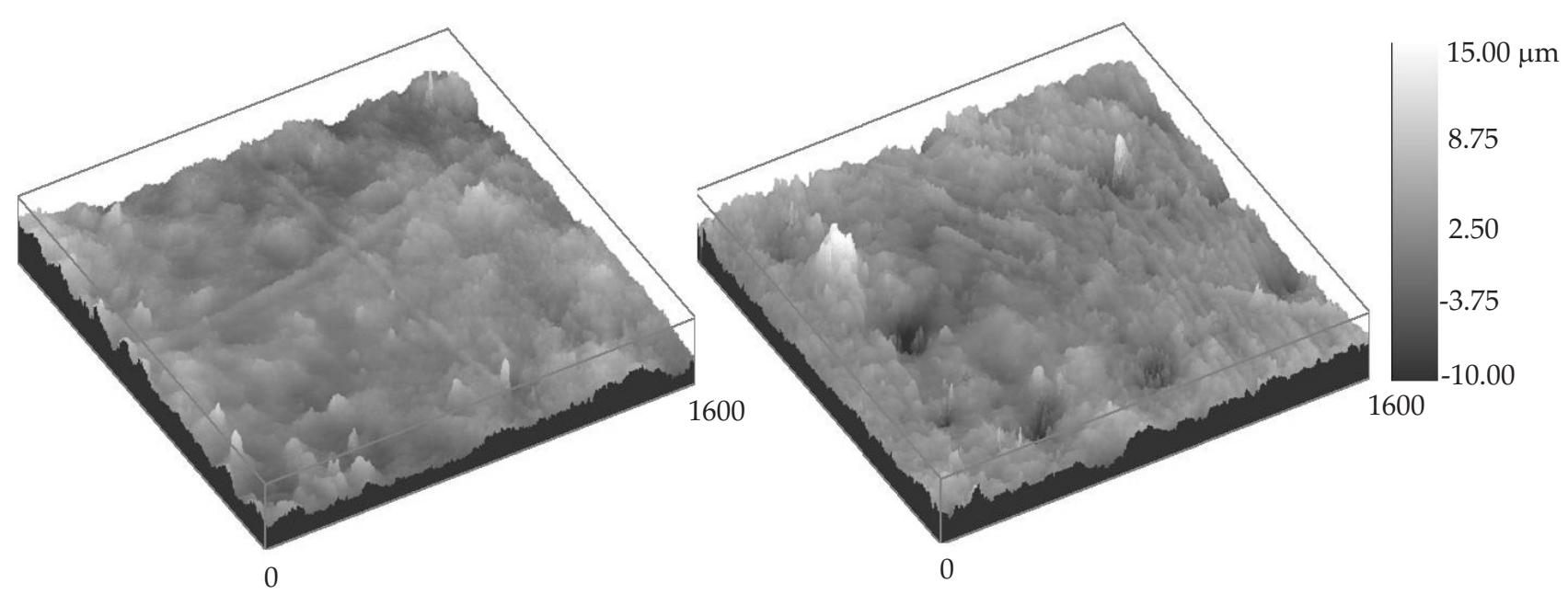

Fig. 2. Confocal microscopy images of PUR-SUC-1 films: a) before, b) after degradation by Novozym 735

ing agent was used (variant II of the synthesis - 1 mole of the extender for each NCO prepolymer group). Typical optical microscopy images of surfaces of original film (PUR--SUC-2), is presented in Fig 1a.

The surface of polyurethane film of PUR-SUC-2 after enzymatic degradation is shown in Fig. 1b. As a result of the action of the degradation solution, both enzymatic degradation of polymer chains and the leaching out of the chemically unbonded excess extender could occur. Small holes, cracks and surface irregularities were initiated on the surface after enzymatic hydrolysis. The formation of surface defects may be due to the penetration of the water into amorphous regions of polyurethane, causing further hydrolysis and enhancing the fragmentation. This indicates that polyurethanes were eroded by a surfacelimited mechanism when exposed to lipase, typical of enzymatic attack.

If the extender is introduced in the quantity corresponding to the functional group content (variant I), the changes in the microscopic picture of the post-degradation sample surface are less insignificant. The picture of the surface of the polyurethane film obtained with su-

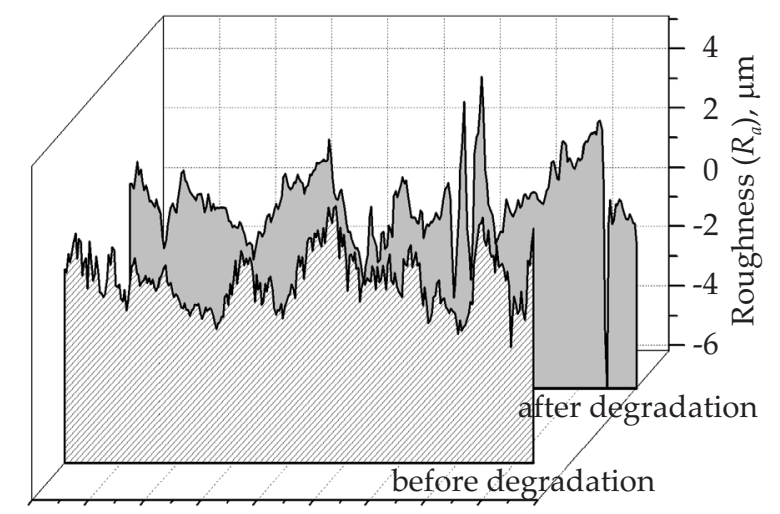

0100200300400500600700800900 Profile length, $\mathrm{m}$

Fig. 3. The roughness profiles of the PUR-SUC-1 surface before and after enzymatic degradation crose used as an extender (PUR-SUC-1), before and after the degradation respectively, obtained as a result of the observation using a confocal microscope is presented in Fig. 2.

Confocal microscopy offered a further advantage over optical microscopy due to the possibility of calculation of roughness parameters of the surfaces. The roughness profiles of PUR-SUC-1 before and after degradation are visualized in Fig. 3.

The roughness profiles of polyurethane films obtained from other extenders after degradation in Novozym 735 are shown in Fig. 4.

The assessment of the geometric structure of the surface was performed as well as the linear measurements of the $X$ and $Y$ axes at selected locations of the surface. Table 2 presents the most important parameters characterising the surface of the selected polyurethane after enzymatic degradation induced by the presence of Novozym 735 .

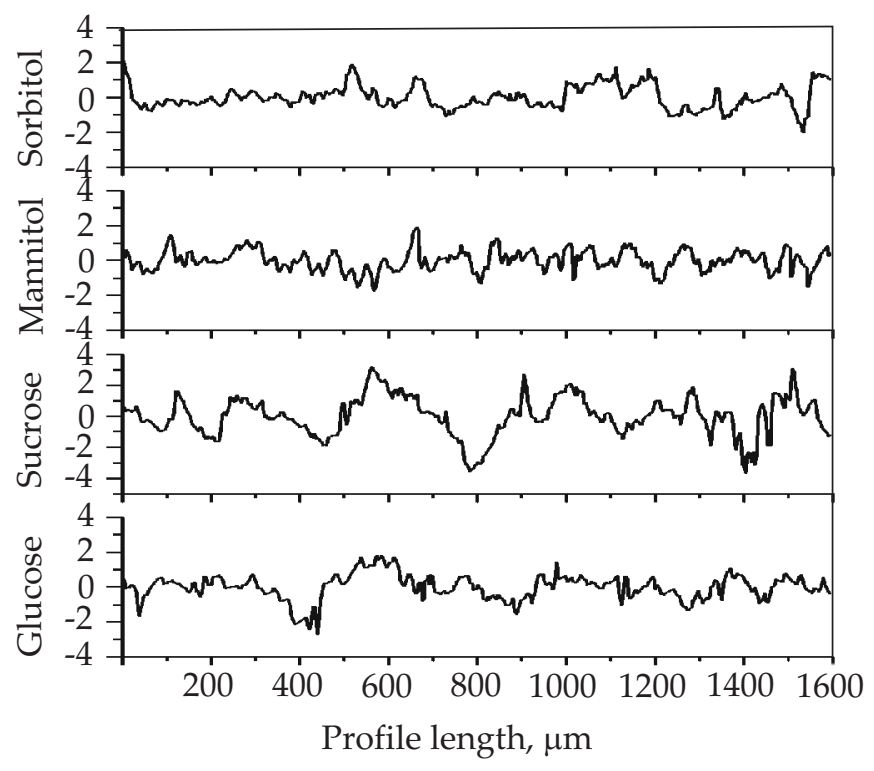

Fig. 4. The roughness profiles of polyurethane films obtained from TMDI, D1200 and different extenders after degradation in Novozym 735 
T a b l e 2. Surface roughness profile parameters of PUR films before and after degradation in Novozym 735

\begin{tabular}{c|c|c|c|c|c|c}
\hline \multirow{2}{*}{ Sample } & \multicolumn{3}{|c|}{ Before degradation } & \multicolumn{3}{c}{ After degradation } \\
\cline { 2 - 7 } & $\begin{array}{c}R_{a} \\
\mu \mathrm{m}\end{array}$ & $\begin{array}{c}R_{q} \\
\mu \mathrm{m}\end{array}$ & $\begin{array}{c}R_{t}=R_{z}=R_{\max } \\
\mu \mathrm{m}\end{array}$ & $\begin{array}{c}R_{a} \\
\mu \mathrm{m}\end{array}$ & $\begin{array}{c}R_{q} \\
\mu \mathrm{m}\end{array}$ & $\begin{array}{c}R_{t}=R_{z}=R_{\max } \\
\mu \mathrm{m}\end{array}$ \\
\hline PUR-GLU-1 & 0.211 & 0.279 & 1.189 & 0.403 & 0.518 & 3.048 \\
PUR-SUC-1 & 0.754 & 0.920 & 4.747 & 0.924 & 1.277 & 7.448 \\
PUR-MAN-1 & 0.160 & 0.222 & 1.169 & 0.362 & 0.469 & 2.071 \\
PUR-SOR-1 & 0.319 & 0.375 & 2.154 & 0.770 & 0.973 & 4.624 \\
PUR-GLU-2 & 0.425 & 0.532 & 1.906 & 0.965 & 1.180 & 7.006 \\
PUR-SUC-2 & 0.944 & 1.187 & 4.748 & 2.531 & 3.355 & 18.411 \\
PUR-MAN-2 & 0.376 & 0.421 & 2.672 & 0.962 & 1.157 & 5.376 \\
PUR-SOR-2 & 0.456 & 0.577 & 2.917 & 1.903 & 2.258 & 11.244 \\
\hline
\end{tabular}

The extent of changes of the roughness of the surfaces differed depending on the type of material tested. It has been found that the roughness average observed for polyurethanes after degradation were approximately two times greater than before enzymatic treatment. Regardless of the variant of the synthesis the maximum values of the surface roughness parameters after degradation were achieved for polyurethanes crosslinked with sucrose.

A quantitative description of the degree of enzymatic degradation was possible by calculating the sample mass loss after degradation. The polyurethane structure determined by the type and amount of the chain extender used affects the extent of sample mass loss after degradation. The application of the amount of the extender ensuring that 1 mole of the natural compound corresponds to 1 mole of -NCO prepolymer (variant II) always results in a greater mass loss than in the case of samples, into which the extender was introduced in an amount required to achieve the $1: 1$ ratio between the modifier functional group and polymer. The mass loss for the synthesized samples according to variant II is 2.5 to 7.5 times higher than for those obtained in accordance with variant I of

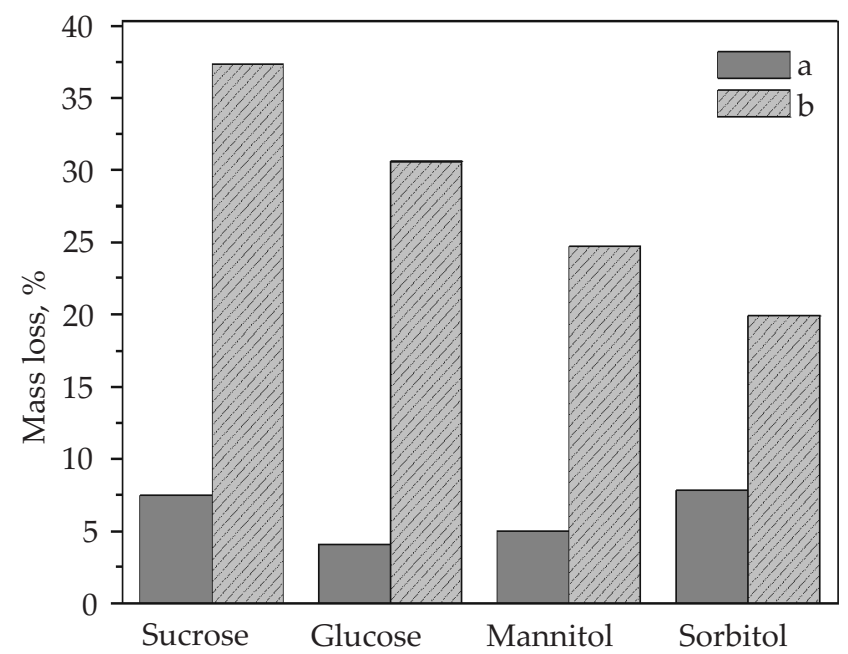

Fig. 5. Mass loss of PUR samples obtained from TMDI, D1200 and different extenders after degradation in Novozym 735: a variant I, b - variant II the synthesis. The trend of the changes does not depend on the kind of the modifier used (Fig. 5).

An analysis of the influence caused by the type of extender on the extent of sample mass loss after degradation shows that the largest mass loss occurred when sucrose was used as the extender.

The data obtained from the sorption experiments were used to calculate molecular weight and degree of crosslinking. The type of extender used did not have a significant effect on swelling as well as degree of crosslinking of PURs because all the extenders are chemically very similar. An extent of sorption not varied significant also with the amount of carbohydrate used for crosslinking. The molecular weight between crosslinks was varied from $2453 \mathrm{~g} / \mathrm{mol}$ for PUR-GLU-1 to $2620 \mathrm{~g} / \mathrm{mol}$ for PUR-SUC-2. The degree of crosslinking was varied from $1.91 \cdot 10^{-4} \mathrm{~mol} / \mathrm{g}$ for PUR-SUC-2 to $2.04 \cdot 10^{-4} \mathrm{~mol} / \mathrm{g}$ for PUR-GLU-1. Unfortunately, correlation between crosslinking density and degradation efficiency of polyurethane elastomers was not so obvious. The differences in the efficiency of enzymatic degradation were rather results from the chemistry of polyurethanes. Hard segments may migrate to and from the surface of the polymer, depending on the nature of surrounding environment. Hydrophilic hard segments which are below the surface in a dry environment migrate to the surface in an aqueous environment. This migration could change the concentration of susceptible bonds both in the bulk and at the interface. On the other hands leaching out of the chemically unbonded excess extender could occur in an aqueous environment because of good solubility of carbohydrate and their derivatives in this environment. In this case of variant II carbohydrates or their derivatives were used also as crosslinkers in the PUR network due to presence of multiple hydroxyl groups that can react with isocyanate groups but also as fillers.

Physical changes in the surface layer are associated with the changes in its chemical structure. In order to visualize the changes on the molecular level, the polyurethanes were examined by means of infrared spectroscopy. The selected spectra of the polyurethane sample (PUR-SUC-1) obtained by means of FT-IR ATR technique, before and after degradation, are shown in Fig. 6. 


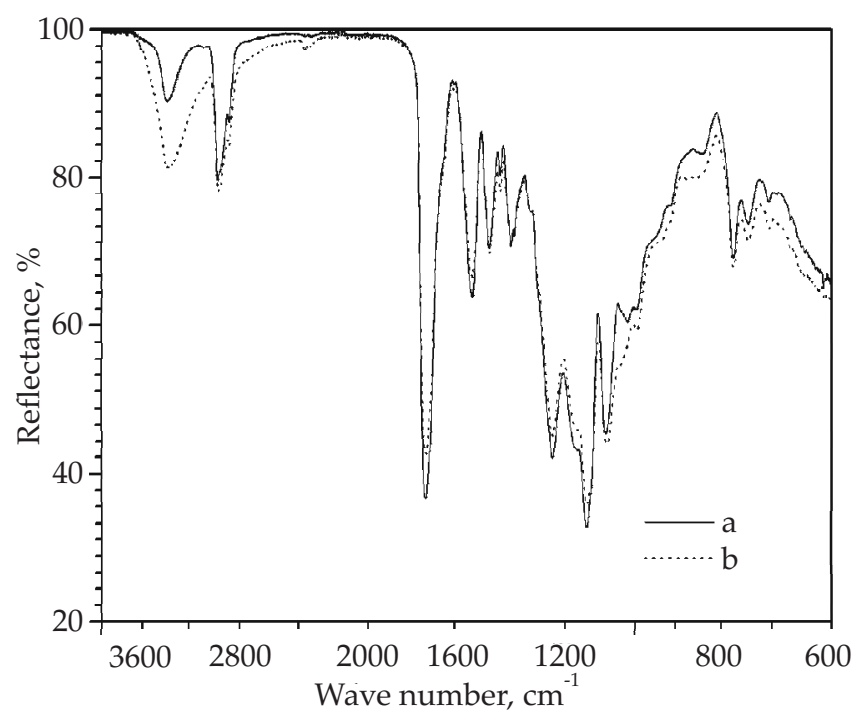

Fig. 6. FT-IR spectra of PUR-SUC-1: a) before, b) after degradation

Characteristically, FT-IR spectra of PUR show absorption bands reflecting vibrations of structural elements: bands of the stretching vibrations of secondary $\mathrm{N}-\mathrm{H}$ amino group which constitutes urethane formation, at $3370 \mathrm{~cm}^{-1}$; bands of the stretching vibrations of $\mathrm{C}=\mathrm{O}$ carbonyl group (assigned to urethane and ester bond) at $1722 \mathrm{~cm}^{-1}$; bands of the combination vibrations of the urethane group at $1524 \mathrm{~cm}^{-1}$, bands of the stretching vibrations of $\mathrm{C}-\mathrm{N}$ and $\mathrm{C}-\mathrm{O}$ asymmetric stretching vibrations at $1234.7 \mathrm{~cm}^{-1}$ of urethane formations and the linkage at $1166 \mathrm{~cm}^{-1}$ (shoulder) corresponds to vibrations of $\mathrm{C}-\mathrm{O}$ which constitutes both urethane formation and ester bond in soft segments.

The spectral region between $1200-800 \mathrm{~cm}^{-1}$ corresponds to the absorption zone of the sugars. Unfortunately this region comprises a series of overlapping bands, mostly resulting from $\mathrm{C}-\mathrm{O}$ and $\mathrm{C}-\mathrm{C}$ stretching vibrations. The precise assignment of these bands is not unequivocal. It is believed that bands characteristic for sucrose are at $993 \mathrm{~cm}^{-1}$ (ring C-C stretching vibrations), $1038 \mathrm{~cm}^{-1}$
(C-O stretching vibration) and $1136 \mathrm{~cm}^{-1}$ (C-O-C bond stretching of the glycosidic bond binding monosaccharides in sucrose).

After the degradation process changes are found in the intensity of the bands at the wave numbers reflecting the vibrations of $\mathrm{N}-\mathrm{H}$ bonds (stretching and deformation) as well as $\mathrm{C}=\mathrm{O}$, and $\mathrm{C}-\mathrm{O}$ bonds. Figure 6 shows decrease in the peak height at $1166 \mathrm{~cm}^{-1}$ and decreased intensity of the bands in the region between 1500 and $1650 \mathrm{~cm}^{-1}$ (C-N stretching and $\mathrm{N}-\mathrm{H}$ bending of urethane/amide linkages) corresponds to degradation of ester and urethane linkages. An increase and broadening of the peak at 3370$3347 \mathrm{~cm}^{-1}$ is attributed to the $\mathrm{H}$-bonded $\mathrm{NH}$ and $\mathrm{OH}$ vibration band of degradation products [30].

Chemical structure of polyurethane chains and their orientation character in the range of domain built from soft and hard segments are deciding on the energy performance of the sample which was quantitatively analyzed by the Owens-Wendt method. The values of the components of the free surface energy of polyurethane films obtained from TMDI, D1200 and various extenders before and after degradation in Novozym 735 are presented in Table 3.

For all the samples undergoing degradation in Novozym 735, regardless of the type and quantity of the extender, an increase in the free surface energy was observed. The percentage increase in the surface free energy is presented in Fig. 7.

It is worth noting that a more significant change of the free surface energy parameters are observed after degradation for polyurethanes synthesised with a considerable excess of the natural extender than for PUR synthesized according to variant I. This is a result of differences in the degree of degradation obtained. For samples obtained according to variant II, the enzymatic action may be intensified by an increase in the area of its action, resulting from the leaching of the superficial layer of the chemically unbonded modifier. The surface becomes rough and coarse and the enzyme molecules may penetrate deeper layers. The greatest changes of the

T a b l e 3. Dispersive $\left(\gamma_{s}^{\mathrm{d}}\right)$ and polar $\left(\gamma_{\mathrm{s}}^{\mathrm{p}}\right)$ components of free surface energy $\left(\gamma_{\mathrm{s}}\right)$ in polyurethanes obtained with different extenders before and after degradation in Novozym 735

\begin{tabular}{|c|c|c|c|c|c|c|}
\hline \multirow{3}{*}{ Sample } & \multicolumn{3}{|c|}{ Before degradation } & \multicolumn{3}{|c|}{ After degradation } \\
\hline & $\gamma_{\mathrm{s}}$ & $\gamma_{\mathrm{s}}^{\mathrm{d}}$ & $\gamma_{\mathrm{s}}^{\mathrm{p}}$ & $\gamma_{\mathrm{s}}$ & $\gamma_{\mathrm{s}}^{\mathrm{d}}$ & $\gamma_{\mathrm{s}}^{\mathrm{p}}$ \\
\hline & \multicolumn{6}{|c|}{$\mathrm{mJ} / \mathrm{m}^{2}$} \\
\hline PUR-GLU-1 & 42.52 & 37.51 & 5.02 & 50.23 & 34.27 & 15.96 \\
\hline PUR-SUC-1 & 42.43 & 37.98 & 4.45 & 54.89 & 31.37 & 23.52 \\
\hline PUR-MAN-1 & 40.08 & 36.97 & 3.11 & 49.67 & 33.01 & 16.66 \\
\hline PUR-SOR-1 & 42.68 & 39.60 & 3.08 & 52.36 & 34.45 & 17.91 \\
\hline PUR-GLU-2 & 43.03 & 43.07 & 0.21 & 53.60 & 28.30 & 25.29 \\
\hline PUR-SUC-2 & 40.88 & 38.21 & 2.67 & 52.21 & 33.19 & 19.02 \\
\hline PUR-MAN-2 & 42.25 & 38.19 & 4.06 & 48.15 & 32.80 & 15.35 \\
\hline PUR-SOR-2 & 41.82 & 37.49 & 4.32 & 50.03 & 33.05 & 16.98 \\
\hline
\end{tabular}




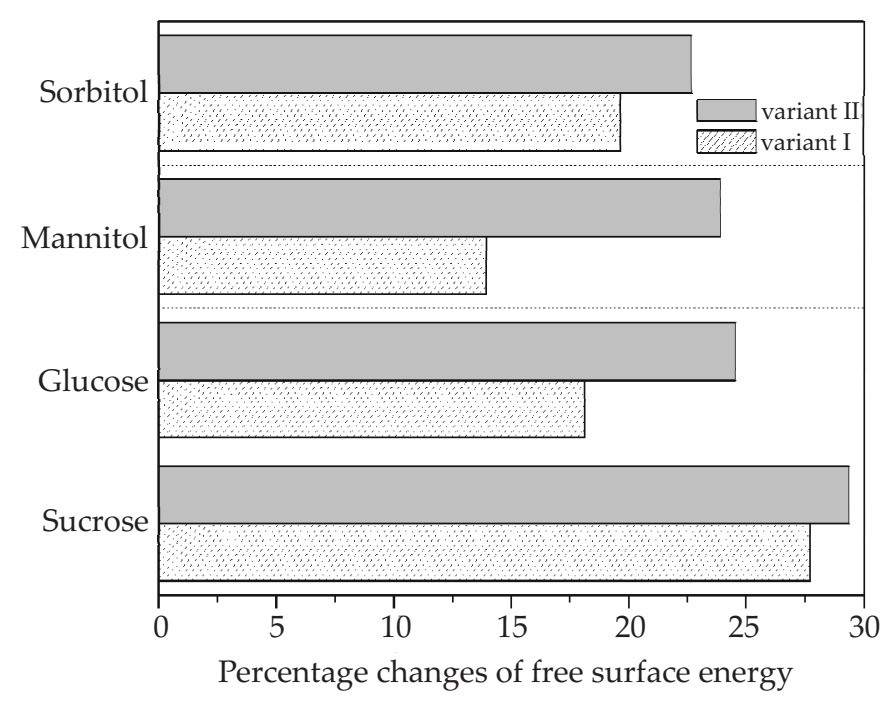

Fig. 7. Influence of variant of synthesis of polyurethane films obtained from TMDI, D1200 and different chain extenders on the percentage changes of free surface energy after degradation in Novozym 735

surface free energy were observed for polyurethanes extended with sucrose.

Before enzymatic degradation the total free surface energy value is determined mainly by the value of the dispersion interactions (quantitatively expressed by using the $\gamma_{\mathrm{s}}^{\mathrm{d}}$ ). The share of the polar component $\gamma_{\mathrm{s}}^{\mathrm{p}}$ amounts only to several $\%(10.5,11.8,7.8$ and $7.2 \%$, respectively for PUR extended by means of sucrose, glucose, mannitol and sorbitol). The influence of the individual components on the total free surface energy value changes decidedly after degradation. The polar component value is increased (its share after degradation amounts to $42.8,31.8,33.5,34.2 \%$, respectively), which shows that the sample becomes more hydrophilic. This nature of changes most probably results from the formation of additional functional groups on the surface of the polymer film (these can include hydroxyl, carboxyl or amine groups), which increase the value $\gamma_{\mathrm{s}}^{\mathrm{p}}$ (Fig. 8). Increase of the free surface energy was the most meaningful for PUR obtained with sucrose as a chain extender.

There was found a relationship between the structure of the rigid segment and the rate of degradation - the higher the number of urethane linkages, the slower the degradation. The ability of the rigid segment in polyurethanes to perform a protective function against hydrolysis may be due the presence of hydrogen bonds inside the rigid segments. Generally, the greater rigid segment share, the slower the degradation.

After the 42-day process of enzymatic degradation thermal analysis of the samples were done (DSC and DTA/DTG). As a result of the enzymatic action affecting the samples, changes are found in the course of the thermogram with regard to the glass transition of hard segments of the polyurethanes (a slight decrease in the glass temperature of the rigid segments occurs). This trend is

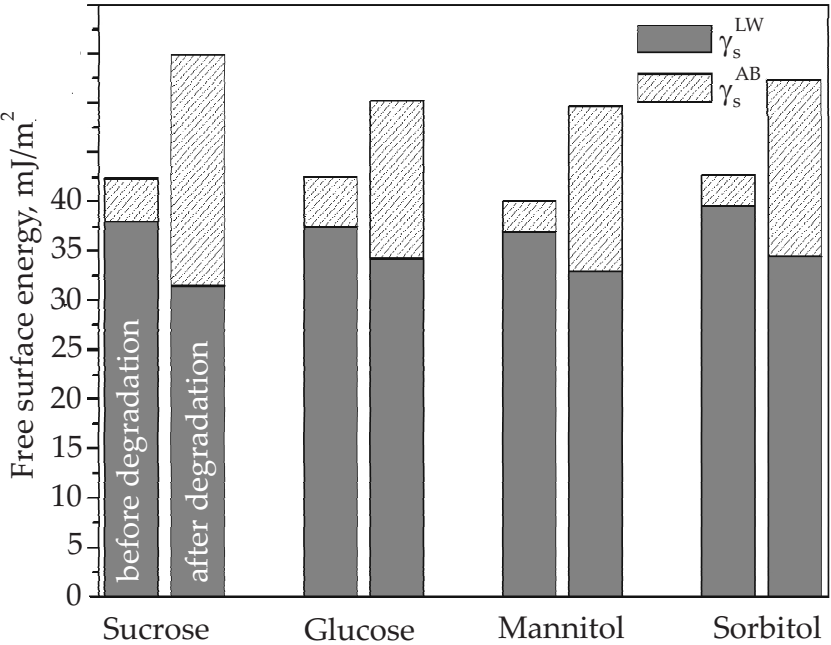

Fig. 8. Parameters of free surface energy of polyurethane coatings obtained from TMDI, D1200 and different chain extenders before and after degradation in Novozym 735

observed regardless of the extender used (Table 4). This nature of changes in glass temperatures probably results from a decrease in the polyurethane molecular mass as a result of the enzymatic action.

The thermal properties of polyurethane films were also examined by means of thermogravimetric analysis. From the results it was found that thermal decomposition mostly depends on amount of extender (Fig. 9). Before degradation, in the case of use excess of natural component (variant II), two step decompositions is observed at about $200-250{ }^{\circ} \mathrm{C}\left(T_{\mathrm{d} 1}\right)$ (melting of not bonded natural component) and at about $350-400{ }^{\circ} \mathrm{C}$ for break-down of ester and urethane bonds in PUR $\left(T_{\mathrm{d} 2}\right)$. When polymerization was realized according the first variant of synthesis only one step decomposition was observed (breakage of urethane bonds) $\left(T_{\mathrm{d} 2}\right)$.

After enzymatic degradation the decomposition of the chemically unbonded extender are not observed since, as a result of the action of the degradation environment, its excess is leached out of the sample. The temperatures of the most rapid mass loss of polyurethane films degraded $\left(T_{\mathrm{d}}\right)$ in the presence of Novozym 735 are presented in the Table 5. The temperature of maximum value of the $\mathrm{d} m / \mathrm{d} T$ curve is moved towards a lower values - which may result from a decrease in the molecular mass of the polymer as a result of enzymatic degradation.

$\mathrm{T}$ a b 1 e 4. Thermal properties of PUR films obtained from D1200, TMDI and different extenders before and after degradation in Novozym 735

\begin{tabular}{c|c|c}
\hline \multirow{2}{*}{ Sample } & \multicolumn{2}{|c}{ Glass transition $T_{g^{\prime}}{ }^{\circ} \mathrm{C}$} \\
\cline { 2 - 3 } & Before degradation & After degradation \\
\hline PUR-GLU-2 & 12.3 & 11.4 \\
PUR-SUC-2 & 9.7 & 9.2 \\
PUR-MAN-2 & 13.0 & 10.2 \\
PUR-SOR-2 & 14.3 & 11.5 \\
\hline
\end{tabular}




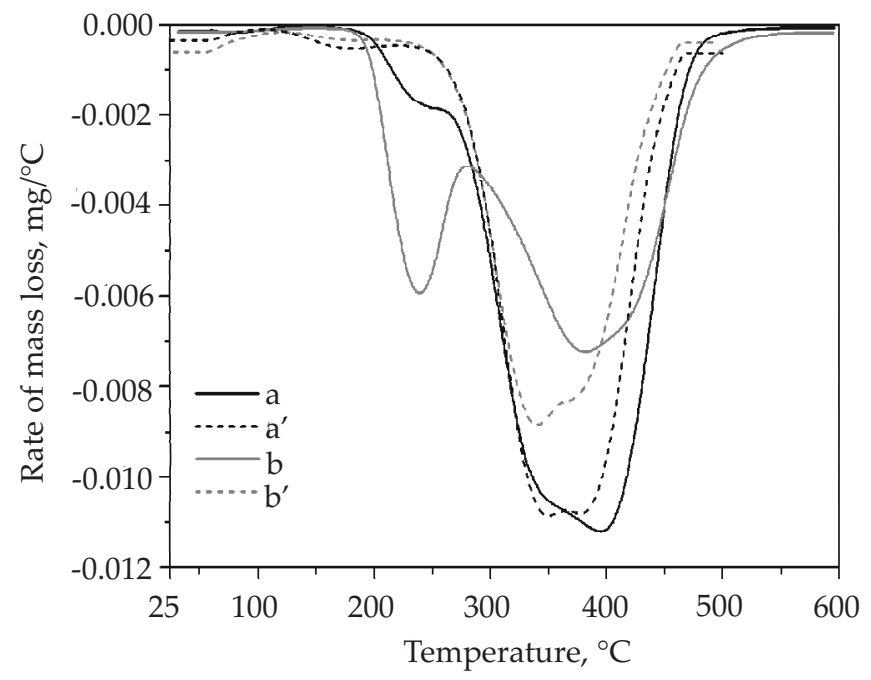

Fig. 9. DTG thermograms of PUR films obtained from D1200, TMDI and sucrose prepared by different manner of the synthesis: PUR-SUC-1: a - before degradation, a' - after degradation, PUR-SUC-2: $b$ - before degradation, $b^{\prime}$ - after degradation

If the synthesis is conducted according to variant II with considerable excess of the extender the changes of the maximum temperature of the decomposition rate of ester and urethane bonds are more significant. The leaching out of the chemically unbonded modifier results in an increase in the contact area between the enzyme contained in the degradation solution and the polyurethane. In consequence, the process of enzymatic degradation is intensified because the enzymatic hydrolysis is a heterogeneous process that is affected by the mode of interaction between the enzymes and the polymeric chains.

The enzymatic degradation rate was evaluated by TOC measurement based on water soluble compounds such us oligomers and other derivatives [28]. It is anticipated that almost all degradation product are water soluble. Tang et al. examined the degradation products from polyurethanes synthesized with HDI, HMDI or MDI by exposing the polymer to cholesterol esterase. The authors separated the products and identified them (13 in case of using HDI, 10 for MDI and 7 for HMDI). Generally these were hydroxyl derivatives which are water soluble [31]. It should be aware of that simultaneously any products with poor solubility in the buffer may occur but they are not identified.

During the degradation process, an increase in the total organic carbon (TOC) content can be observed in the environment of enzymatic hydrolysis. An increase in TOC was also noted in degradation solutions containing a polymer sample $\left(T O C_{\mathrm{S}, \mathrm{E}, \mathrm{B}}\right)$, as well as in reference solutions, i.e. in systems consisting only of buffer and enzyme $\left(T O C_{\mathrm{B}, \mathrm{E}}\right)$, (Fig. 10).

The intensity of TOC changes depends on the chemical composition of the sample. In polyurethane films, in which an excess modifier was used (variant II), a chemically unbonded modifier may be leached out. If a natural compound is introduced at an amount corresponding to

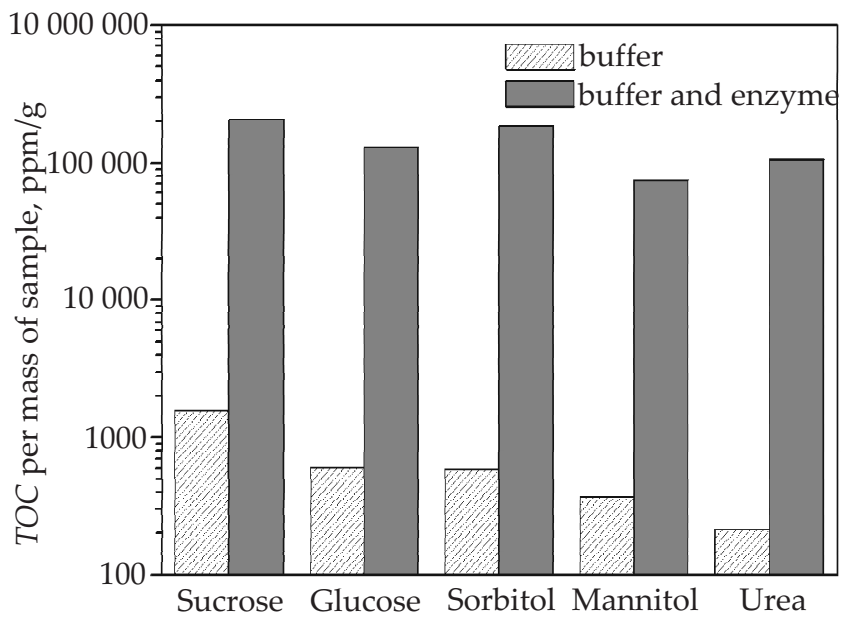

Fig. 10. Total organic carbon concentration (TOC) in the solutions after the enzymatic degradation of polyurethane films obtained from TMDI, D1200 and different carbohydrates in Novozym 735 (variant I)

functional relationships, an increase in the total organic carbon content in degradation solutions is observed, but it results only from the formation of water-soluble decomposition products of the sample. The quantity of these products depends on the kind of modifier - enzymatic degradation is the most effective if sucrose is used. The effectiveness of the enzymatic degradation process is presented in Table 6.

\section{CONCLUSIONS}

The results obtained for the enzymatic degradation study for carbohydrate based polyurethane elastomers showed that all the prepared samples were partially de-

T a b l e 5. Main thermogravimetric data of the selected polyurethane samples

\begin{tabular}{c|c|c|c}
\hline \multirow{2}{*}{ Sample } & \multicolumn{3}{|c}{$T_{\mathrm{d}^{\prime}}{ }^{\circ} \mathrm{C}$} \\
\cline { 2 - 4 } & \multicolumn{2}{|c}{ Before degradation } & $\begin{array}{c}\text { After degra- } \\
\text { dation }\end{array}$ \\
\cline { 2 - 4 } & $T_{\mathrm{d} 1}$ & $T_{\mathrm{d} 2}$ & $T_{\mathrm{d} 2}$ \\
\hline PUR-GLU-2 & 244 & 379 & 341 \\
PUR-SUC-2 & 243 & 387 & 341 \\
PUR-MAN-2 & 290 & 400 & 339 \\
PUR-SOR-2 & 291 & 392 & 338 \\
\hline
\end{tabular}

T a b 1 e 6. Measurements of solubilized carbon from PURs by lipase-degradation

\begin{tabular}{c|c|c|c}
\hline Sample & TOC $_{\mathrm{T}^{\prime}} \mathrm{ppm}$ & $\mathrm{TOC}_{\mathrm{N}^{\prime}} \mathrm{ppm}$ & $E_{\mathrm{bio}^{\prime}} \%$ \\
\hline PUR-GLU-1 & 10724 & 771 & 7.2 \\
PUR-SUC-1 & 6626 & 901 & 13.6 \\
PUR-MAN-1 & 12934 & 204 & 1.6 \\
PUR-SOR-1 & 18588 & 787 & 4.2 \\
\hline
\end{tabular}


graded. After 6 weeks immersion in aqueous phosphate buffer solutions containing enzyme at $37^{\circ} \mathrm{C}$, changes were noticed in respect to appearance, roughness, weight of samples and their thermal properties. Spectroscopic and microscopic observations confirmed the degradation effect mainly at the surface level of the studied samples. The changes of the free surface energy parameters also confirmed surface deterioration occurred for all obtained samples. The enzymatic degradation of polyurethanes is ruled by amount and type of carbohydrate. It was observed that huge excess of extender caused meaningful changes in polymer surface after enzymatic degradation. The most significant changes were observed for samples including sucrose. The more hydrophilic materials with some degree of branching presented an enhanced degradation progression.

\section{ACKNOWLEDGMENTS}

The author would like to thank Bayer A.G., Evonik Degussa G.m.b.H. and Novozymes for sending free samples of raw materials.

\section{REFERENCES}

[1] Xiea F., Zhanga T., Bryante P. et al.: Progress in Polymer Science 2019, 90, 211.

https://doi.org/10.1016/j.progpolymsci.2018.12.003

[2] Solankia A., Dasa M., Thakore S.: Carbohydrate Polymers 2018, 181, 1003.

https://doi.org/10.1016/j.carbpol.2017.11.049

[3] Schmidt J., Wei R., Oeser T. et al.: Polymers 2017, 9, 65. https://doi.org/10.3390/polym9020065

[4] Duguay D.G., Labow R.S., Santerre J.P., McLean D.D.: Polymer Degradation and Stability 1995, 47, 229. http://dx.doi.org/10.1016/0141-3910(94)00114-N

[5] Ciardelli G., Rechichi A., Cerrai P.et al.: Macromolecular Symposia 2004, 218, 261.

http://dx.doi.org/10.1002/masy.200451427

[6] Gautam R., Bassi A.S., Yanful E.K.: Biotechnology Letters 2007, 29, 1081. http://dx.doi.org/10.1007/s10529-007-9354-1

[7] Shi R., Chen D., Liu Q. et al.: International Journal of Molecular Sciences 2009, 10, 4223. http://dx.doi.org/10.3390/ijms10104223

[8] Christenson E.M., Patel S., Anderson J.M., Hiltner A.: Biomaterials 2006, 27, 3920. http://dx.doi.org/10.1016/j.biomaterials.2006.03.012

[9] Magnin A., Pollet E., Perrin R. et al.: Management 2019, 85, 141.

https://doi.org/10.1016/j.wasman.2018.12.024

[10] Gamerith C., Herrero Acero E., Pellis A. et al.: Polymer Degradation and Stability 2016, 132, 69.

http://dx.doi.org/10.1016/j.polymdegradstab.2016.02.025

[11] Howard G.D.: International Biodeterioration \& Biodegradation 2002, 49, 245. http://dx.doi.org/10.1016/S0964-8305(02)00051-3
[12] Santerre J.P., Woodhouse K., Laroche G., Labow R.S.: Biomaterials 2005, 26, 7457. http://dx.doi.org/10.1016/j.biomaterials.2005.05.079

[13] Nakajima-Kambe T., Shigeno-Akutsu Y., Nomura N., Nakahara T.: Applied Microbiology and Biotechnology 1999, 51, 134. http://dx.doi.org/10.1007/s002530051373

[14] Santerre J.P., Labow R.S.: Journal of Biomedical Materials Research 1997, 36, 223.

h t t p://dx.doi.org/10.1002/(SIC I) 1097 4636(199708)36:2\%3C223::AID-JBM11\%3E3.0.CO;2-H

[15] Fenouillot F., Rousseau A., Colomines G. et al.: Progress in Polymer Science 2010, 35, 578. http://dx.doi.org/10.1016/j.progpolymsci.2009.10.001

[16] Oprea S., Potolinca V.O., Oprea V.: European Polymer Journal 2016, 83, 161. http://dx.doi.org/10.1016/j.eurpolymj.2016.08.020

[17] Takahara A., Hadano M., Yamaguchi T. et al.: Macromolecular Symposia 2005, 224, 207. https://doi.org/10.1002/masy.200550618

[18] Kloss J., de Souza F.S.M., da Silva E.R. et al.: Macromolecular Symposia 2006, 245-246, 651. http://dx.doi.org/10.1002/masy.200651392

[19] Marín R., Violante de Paz M., Ittobane N. et al.: Macromolecular Chemistry and Physics 2009, 210, 486. http://dx.doi.org/10.1002/macp.200800517

[20] Zia K.M., Barikani M., Bhatti I.A. et al: Journal of Applied Polymer Science 2008, 110 (2), 769. http://dx.doi.org/10.1002/app.28533

[21] Silva S.S., Menezes S.M.C., Garcia R.B.: European Polymer Journal 2003, 39 (7), 1515. http://dx.doi.org/10.1016/S0014-3057(03)00013-2

[22] Alves P., Coelho J.F.J., Haack J. et al.: European Polymer Journal 2009, 45 (5), 1412. http://dx.doi.org/10.1016/j.eurpolymj.2009.02.011

[23] Kadnaim A., Janvikul W., Achai U., Rutnakornpituk M.: Carbohydrate Polymers 2008, 74 (2), 257. http://dx.doi.org/10.1016/j.carbpol.2008.02.007

[24] Wu D.D., Tan Y., Cao Z.W. et al.: Carbohydrate Polymers 2018, 194, 236. https://doi.org/10.1016/j.carbpol.2018.04.034

[25] Solankia A., Mehta J., Thakore S.: Carbohydrate Polymers 2014, 110, 338. http://dx.doi.org/10.1016/j.carbpol.2014.04.021

[26] Romero-Azogil L., Benito E., Martínez de Ilarduya A. et al.: Polymer Degradation and Stability 2018, 153, 262. https://doi.org/10.1016/j.polymdegradstab.2018.05.009

[27] Giese Jr R.F., van Oss C.J.: "Colloid and Surface Properties of Clays and Related Minerals", New York: Marcel Dekker, 2002, p. 141. http://dx.doi.org/10.1201/9780203910658

[28] Yamamoto N., Nakayama A., Oshima M. et al.: Reactive \& Functional Polymer 2007, 67, 1338. http://dx.doi.org/10.1016/j.reactfunctpolym.2007.08.011

[29] Król P. , Wojturska J.: Journal of Applied Polymer Science 2006, 101, 3511. 
http://dx.doi.org/10.1002/app.24581

[30] Oprea S.: Polymer Degradation and Stability 2010, 95, 2396.

https://doi.org/10.1016/j.polymdegradstab.2010.08.013
[31] Tang Y.W., Labow R.S., Santerre J.P.: Biomaterials 2003, 24 (17), 2805.

http://dx.doi.org/10.1016/S0142-9612(03)00081-4

Received 30 VII 2019.

\section{International Scientific-Technical Conference "Advance in Petroleum and Gas Industry and Petrochemistry"}

Lviv, Ukraine, May 18-23, 2020

Chairman of the Scientific Committee: prof. Yuri Bobalo (Rector of Lviv Polytechnic National University, Ukraine) Chairman of the Organizing Committee: prof. Michael Bratychak (Lviv Polytechnic National University, Ukraine)

Topics:

- Oil and gas processing

- Petrochemistry and coal chemistry

- Chemmotology of lubricants and technical liquids

- Organic synthesis products

Conference languages: Ukrainian/English

\section{Deadlines:}

Deadline for registration - March 14, 2020

Deadline for conference materials - April 1, 2020

Deadline for payment - April 10, 2020

Registration fee: Full fee - 250 EUR, accompanying person - 100 EUR, students and post-graduate students 150 EUR (registration fee includes: information supplying, conference materials, coffee)

Account for payment (EUR):

Beneficiary: Lviv Polytechnic Alumni Association

Bank of Beneficiary: INTERNATIONAL INVESTMENT BANK

Bank Address: 16, Lavrska str., Kyiv, Ukraine

IBAN: UA753805820000026002010325122, SWIFT code: IINBUAUK, Corraccount No.: 400886675800

Purpose of payment: registration fee for APGIP-10, Name of the participant

Be sure your Name is written and inform us about the date of transfer

\section{Contact:}

Chairman: Michael Bratychak, +38032 25821 66, +380 5050152 38, e-mail: mbratychak@gmail.com

Co-chairman: Oleh Hrynyshyn, +38067 8000148, e-mail: ogrynyshyn@ukr.net

Secretary: Prysiazhnyi Iyrii, + 38097 6408031, e-mail: apgip10@gmail.com

Address: Ukraine, Lviv, 3/4, St.Yura Sq., acad. building VIII of Lviv Polytechnic National University

\section{http://apgip.org.ua/}

